\title{
A Framework for Assessing the Vulnerability of Archaeological Sites to Climate Change: Theory, Development, and Application
}

\author{
CATHY DALY
}

Dublin Institute of Technology, Ireland

The predicted impacts of climate change on cultural heritage are likely to be dynamic and complex. Understanding the potential risks at site level is vital to ensure that appropriate adaptation and mitigation measures are put in place. There is, however, a dearth of tools and methodologies suitable for use by heritage managers. In this paper the potential of vulnerability analysis for site-based assessment is explored. A six-step vulnerability framework, adapted for cultural heritage, is illustrated utilizing material from two case-study sites (Brú na Bóinne and Skellig Michael). The implementation of each step in the proposed framework is demonstrated to aid those wishing to apply the method in practice. The 'values based' approach taken is suitable for a wide range of cultural heritage including landscapes, monuments, and buried archaeology. The six-step framework and the utilization of indicators provide a method that allows comparison between sites and yet is sufficiently flexible to account for localized concerns. The framework will aid decision makers with planning and prioritization.

KEYWORDS climate change, vulnerability assessment, cultural value, heritage management, World Heritage

\section{Introduction}

\footnotetext{
Although it is conceptually quite simple to envisage the impact of climate change on individual processes, the difficulty comes in trying to weigh up the importance of different impacts. (Viles, 2002: 4I0)
}

The impacts of climate change on heritage values are likely to be dynamic and complex (Figure I). Thus any assessment of climate change risk at site level will require a multi-facetted approach capable of addressing the many variables and uncertainties 


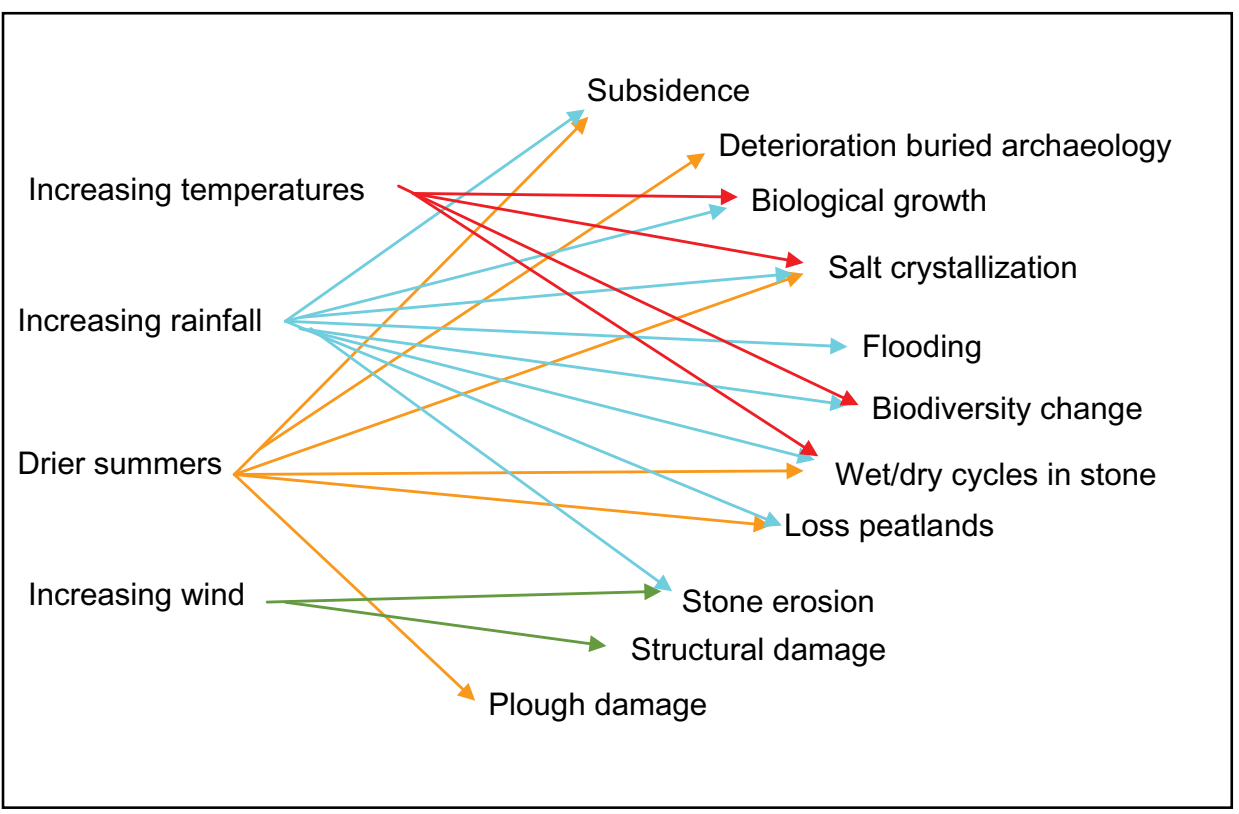

FIGURE 1 Multiple interactions: Climate change factors and impacts (Daly, et al., 2010).

involved. It will be argued in this paper that 'vulnerability analysis' answers these requirements. An exploration of the theoretical development of vulnerability analysis and of the methods documented in the literature will be carried out. The methodology chosen and its adaptation for use at heritage sites will be detailed and demonstrated utilizing material from two case-study World Heritage sites in Ireland (Brú na Bóinne and Skellig Michael). The material presented here is part of the author's doctoral thesis for the Dublin Institute of Technology funded by ABBEST (Daly, 20I4).

\section{Vulnerability and climate change}

Assessing vulnerabilities to climate change, as opposed to carrying out risk analysis, has become a common approach in many sectors since the IPCC issued its Third Assessment Report (TAR) (Hinkel, 20I ; Adger, 2006; The Allen Consulting Group, 2005). That report recommended vulnerability assessment as a precursor to developing adaptation responses to climate change impacts (Figure I). The advantage of the vulnerability approach over traditional risk analysis ${ }^{\mathrm{I}}$ is that it does not rely solely on an evaluation of exposure and sensitivity to hazards, but also on the internal ability of a system to adapt and recover (Turner, et al., 2003a; Luers, et al., 2003). Vulnerability analysis entails a holistic approach, it recognizes that humans and the environment are inextricably linked, and analysts therefore assess what is termed the 'coupled human-environment system'.

The TAR definition of vulnerability is widely referred to in the literature (Adger, et al., 2004; The Allen Consulting Group, 2005; Hinkel \& Klein, 2006; Ford \& Smit, 2004). It defines vulnerability as: 
The degree to which a system is susceptible to, or unable to cope with, adverse effects of climate change, including climate variability and extremes. Vulnerability is a function of the character, magnitude, and rate of climate variation to which a system is exposed, its sensitivity, and its adaptive capacity. (McCarthy, et al., 200I: Annex B)

While this definition states that vulnerability is a function of exposure, sensitivity, and adaptive capacity, it has been criticized for failing to explain this relationship or to give direction to those seeking to apply the theory into practice (Adger, et al., 2004; Hinkel \& Klein, 2006). The result of this lack of clarity is that, while the terminology may be common across studies, methods of analysis can vary quite substantially.

\section{Vulnerability analysis in practice}

As a growing field with multi-disciplinary origins, it is not surprising that there are a variety of approaches described as vulnerability assessment. Currently, formulations stem from the needs of each individual case and there is no single recognized way of analysing cause and effect within systems (Adger, 2006). The multiple concepts and applications published in the literature can therefore be confusing for an individual attempting to conduct an assessment. For example, the US National Park Service's vulnerability assessment of coastal heritage resources takes a 'biophysical' approach using a combination of desk top mapping and site visits to produce the assessment (Toscano, 2004). Although there is a strong place-based element in this assessment, the final result takes very little account of socio-economic factors involved, and is not very different to risk analysis. In another example, the Great Barrier Reef (GBR) Marine Park World Heritage site in Australia produced a vulnerability analysis of the site to climate change impacts (Marshall \& Johnson, 2007). The analysis is qualitative, based on past vulnerabilities and expert judgement, and adaptive capacity is considered in relation to indigenous culture and coastal industries. In the Summary of Impacts, however, each impact is assessed according to vulnerability, certainty, and timeframe, more akin to the probability and magnitude rankings of risk analysis than vulnerability theory, despite the terminology.

Ford and Smit concluded from their literature survey that there were two basic approaches to vulnerability: biophysical and social (Ford \& Smit, 2004). In the 'biophysical' approach, vulnerability is conceptualized as a pre-existing condition determined by exposure and sensitivity to hazard, it is similar to risk but differs in the absence of probability as a function (Adger, et al., 2004). In the 'social' approach, vulnerability is dependent on the social, political, and economic determinants that control resistance and recovery, i.e. adaptive capacity. A growing number of researchers are now combining these two approaches (Turner, et al., 2003 b).

\section{Terminology: the three elements of vulnerability}

Existing terms and definitions for the three elements of vulnerability (sensitivity, exposure, and adaptive capacity) require adaptation for application to heritage systems.

\section{Exposure}

The IPCC definition of exposure speaks only of climatic variations and not other changes in the environmental system brought about by climate effects, stating 
exposure is the nature and degree to which a system is exposed to significant climatic variations (McCarthy et al., 200I: Annex B). This can be adapted for cultural heritage by including 'related impacts' and specifying a values-based approach. The suggested definition is:

Exposure is the degree to which an identified heritage value is exposed to climatic variations and their related impacts. It is determined by environmental conditions (physical and atmospheric).

\section{Sensitivity}

Sensitivity of tangible heritage is likely to be dependent on material properties and physical condition or integrity, while at system level environmental or organizational fragility would also be relevant. Using the IPCC TAR wording (McCarthy, et al., 200I: Annex B) as a starting point, the proposed definition for sensitivity of cultural heritage refers to 'value' and also specifies scale:

Sensitivity is the degree to which an identified heritage value is affected, either adversely or beneficially, by [climate-related] stimuli. The effect may occur at artefact, assemblage or system level.

\section{Adaptive capacity}

Unlike exposure and sensitivity, this is not an inherent quality of the system and deliberate efforts to increase the capacity to cope with (or avoid) the impacts of climate change are possible (The Allen Consulting Group, 2005). The IPCC defines adaptive capacity as:

The ability of a system to adjust to climate change (including climate variability and extremes), to moderate potential damages, to take advantage of opportunities, or to cope with the consequences. (McCarthy, et al., 200I: Annex B)

This applies for any system and does not need to be reworded for application to cultural heritage.

\section{Vulnerability}

Based on the IPCC wording (McCarthy, et al., 200I: Annex B) the following definition for the vulnerability of cultural heritage to climate change is proposed:

Vulnerability is the degree to which an identified cultural heritage value is susceptible to, or will be adversely affected by, effects of climate change, including climate variability and extremes. Vulnerability (V) is a function of exposure (E), sensitivity (S), and adaptive capacity $(\mathrm{AC})$ as represented by the equation $\mathrm{V}=(\mathrm{E}+\mathrm{S})-\mathrm{AC}$.

\section{Designing a vulnerability assessment framework}

There is a desperate need for tools that can assess risks to archaeological sites from environmental threats. (Holden, et al., 2006: 80)

An eight-step method to guide vulnerability assessments published in 2005 (Schröter, et al., 2005) was recommended by the UNESCO report on strategies for managing 
TABLE 1

COMPARISON OF NEW SIX-STEP VULNERABILITY FRAMEWORK WITH PREVIOUS EXAMPLES BY SCHRÖTER (2005) AND WOODSIDE (2006)

\begin{tabular}{|c|c|c|}
\hline $\begin{array}{l}\text { Eight-step framework (Schröter, et } \\
\text { al., 2005) }\end{array}$ & Woodside's five steps (2006) & $\begin{array}{l}\text { Six-step vulnerability assessment } \\
\text { framework }\end{array}$ \\
\hline Define study area & Define study area & $\begin{array}{l}\text { Define the heritage values to be } \\
\text { assessed }\end{array}$ \\
\hline $\begin{array}{l}\text { Get to know the place over time } \\
\text { (understand exposure, sensitivity, } \\
\text { and adaptive capacity) }\end{array}$ & $\begin{array}{l}\text { Define the significance of the } \\
\text { asset }\end{array}$ & $\begin{array}{l}\text { Understand exposure, sensitivity, and } \\
\text { adaptive capacity of these values } \\
\text { over time }\end{array}$ \\
\hline $\begin{array}{l}\text { Hypothesize who is vulnerable } \\
\text { to what }\end{array}$ & Identify most likely hazards & $\begin{array}{l}\text { Identify likely hazards for each value } \\
\text { under future climate using the Matrix } \\
\text { of Impacts }\end{array}$ \\
\hline $\begin{array}{l}\text { Develop a causal model of } \\
\text { vulnerability (exposure, sensitivity, } \\
\text { adaptive capacity) }\end{array}$ & $\begin{array}{l}\text { Assess exposure and sensitivity } \\
\text { Assess adaptive capacity }\end{array}$ & $\begin{array}{l}\text { Develop indicators for the elements } \\
\text { of vulnerability }\end{array}$ \\
\hline $\begin{array}{l}\text { Find indicators for the elements of } \\
\text { vulnerability }\end{array}$ & $\begin{array}{l}\text { Quantify vulnerability and } \\
\text { develop indicators }\end{array}$ & $\begin{array}{l}\text { Assess vulnerability by entering } \\
\text { values for exposure, sensitivity, and } \\
\text { adaptive capacity into the Causal } \\
\text { Model (table } 6.2 \text { ) }\end{array}$ \\
\hline $\begin{array}{l}\text { ‘Operationalize' model of } \\
\text { vulnerability }\end{array}$ & & $\begin{array}{l}\text { Use Stakeholder Review to refine } \\
\text { and communicate results }\end{array}$ \\
\hline \multicolumn{3}{|l|}{ Project future vulnerability } \\
\hline $\begin{array}{l}\text { Communicate vulnerability } \\
\text { creatively }\end{array}$ & & \\
\hline
\end{tabular}

climate change (Colette, 2007). Unlike some vulnerability techniques, this is a 'placebased' approach, designed for specific stakeholders, allowing public and collaborative professional involvement (Turner, et al., 2003a). In a Master's thesis for University College London, Woodside applied the Schröter methodology to an assessment of the Tower of London World Heritage site (Woodside, 2006). Following on from the work of Schröter and Woodside a six-stage framework (Table I) for assessing the vulnerability of cultural heritage to climate change was developed and implemented by the author at two case-study sites in Ireland, Brú na Bóinne and Skellig Michael.

\section{Implementing the six-step framework}

\section{Step 1: Define the heritage values to be assessed}

This first step requires knowledge of the nature and extent of all heritage values considered important for the site. For example, are views important or specific elements of the landscape? In some cases these will be defined in existing conservation plans or designation documents. Spatial boundaries should also be determined at this point, if not already established. The case-study sites were World Heritage (WH) properties and already have clearly defined boundaries and described values. The vulnerability of the sites was analysed at different levels, accounting for both national and $\mathrm{WH}$ values (Table 2 ). 
TABLE 2

EXAMPLE OF VALUE CATEGORIES FOR CONDUCTING VULNERABILITY ASSESSMENT

\begin{tabular}{ll}
\hline Skellig Michael values & Brú na Bóinne values \\
\hline Monastic structures and features & Rock art \\
Buried deposits & Passage tomb structures \\
Cultural Landscape & Buried deposits \\
& Cultural Landscape \\
\hline
\end{tabular}

\section{Step 2: Understand exposure, sensitivity, and adaptive capacity of these values over time}

Vulnerability is a function of three elements (exposure, sensitivity, and adaptive capacity) and the widest possible range of primary and secondary sources should be used to gain an understanding of these factors (Turner, et al., 2003 b). At the casestudy sites this included both published and unpublished documentation, repeated site visits and interviews with stakeholders. Site visits develop a first-hand understanding of the relationship between the heritage values and the surrounding environment, such as topography, aspect, patterns of wear, and land use. Ideally, the site should be visited in different seasons to ascertain any areas prone to seasonal effects such as flooding or frost. Stakeholders may include heritage professionals, researchers, site staff, local residents, or visitors. They should represent a wide breadth and depth of knowledge. During the case-study assessments structured interviews were undertaken with stakeholders around how climate has, and may in the future, impact on heritage values. The interviewees were shown an impacts matrix (Table 3 ) to help them identify issues of concern under future climate change.

Future climate conditions can be ascertained from a suitable Regional Climate Model (RCM). Downscaled RCM projections with a resolution of Io $\mathrm{km}^{2}$ were utilized for the case studies. The data was provided by the Max Plank Institute under the auspices of Climate for Culture (CfC) from the REMO 2009 regional climate model (Jacob, et al., 20I2). In addition to the standard parameters of temperature, precipitation, and radiation, the $\mathrm{CfC}$ data included specific concerns for heritage such as $\mathrm{RH}$, surface temperature, and wind direction. Managers should be cognisant that different emissions storylines underlie climate projections and that they may not indicate the 'worst case scenario'. For example, the CfC model uses a medium-low emissions storyline and actually represents a fairly positive view of the future. For the purposes of assessing the case studies, the control period (I960-9I) was compared with the far future period (2070-2IOI) (e.g. Table 4).

\section{Exposure}

By combining future projections with evidence gathered from stakeholders and secondary research, it becomes possible to describe the exposure of heritage values to the main climatic parameters (wind, rainfall, and temperature) and their associated impacts (e.g. Table 5). 
TABLE 3

IMPACTS MATRIX

\begin{tabular}{lcccc}
\hline No. of days/quarter with rainfall $>5 \mathrm{~mm} / \mathrm{hr}$ & Jan-Mar & Apr-Jun & Jul-Sep & Oct-Dec \\
\hline $1960-91$ & 12 & 16 & 33 & 23 \\
2070-2101 & 10 & 27 & 72 & 50 \\
Projected change & $\uparrow 17 \%$ & $\uparrow 69 \%$ & $\uparrow 118 \%$ & $\uparrow 117 \%$ \\
\hline
\end{tabular}

TABLE 4

INTENSITY OF PRECIPITATION PROJECTIONS FOR BRÚ NA BÓINNE (REMO MODEL/IPCC AR4 A1B SCENARIO)

\begin{tabular}{|c|c|c|}
\hline Climatic parameter and impact & Degree of exposure & Comment \\
\hline $\begin{array}{l}\text { Rainfall - impact on flooding, } \\
\text { landscape use, wetting and drying } \\
\text { patterns, salt, and microbiological } \\
\text { activity. Summer drought } \\
\text { leading to vegetation die back, } \\
\text { soil erosion, subsidence, and } \\
\text { deterioration of water quality. } \\
\text { The REMO model shows drier } \\
\text { summers and wetter winters. The } \\
\text { greatest change in precipitation is } \\
\text { in increased intensity. }\end{array}$ & $\begin{array}{l}\text { There is a } 90 \% \text { rise in the } \\
\text { number of days where rainfall } \\
\text { is projected to exceed } 5 \mathrm{~mm} / \\
\text { hour. July-September will see the } \\
\text { greatest escalation in heavy rain, } \\
\text { followed by October-December. } \\
\text { The decrease in summer volume } \\
\text { (July) at } 7 \% \text { is significant when } \\
\text { combined with } 2-3^{\circ} \text { C. Rise in } \\
\text { ground temperatures. }\end{array}$ & $\begin{array}{l}\text { Concrete canopies at Knowth } \\
\text { and Newgrange partially shelter } \\
\text { the kerbstones from horizontal } \\
\text { rain. Although volume remains } \\
\text { constant, the shift towards short } \\
\text { periods of intense rainfall will } \\
\text { alter wetting and drying cycles } \\
\text { considerably. Concerns expressed } \\
\text { for K1, the exposed entrance } \\
\text { stone at Newgrange. }\end{array}$ \\
\hline
\end{tabular}

TABLE 5

POTENTIAL IMPACTS AND DEGREE OF EXPOSURE TO PREDICTED CHANGES IN RAINFALL (BRÚ NA BÓINNE)

\begin{tabular}{|c|c|c|}
\hline Climatic parameter and impact & Degree of exposure & Comment \\
\hline $\begin{array}{l}\text { Rainfall - impact on flooding, } \\
\text { landscape use, wetting and drying } \\
\text { patterns, salt, and microbiological } \\
\text { activity. Summer drought } \\
\text { leading to vegetation die back, } \\
\text { soil erosion, subsidence, and } \\
\text { deterioration of water quality. } \\
\text { The REMO model shows drier } \\
\text { summers and wetter winters. The } \\
\text { greatest change in precipitation is } \\
\text { in increased intensity. }\end{array}$ & $\begin{array}{l}\text { There is a } 90 \% \text { rise in the } \\
\text { number of days where rainfall } \\
\text { is projected to exceed } 5 \mathrm{~mm} / \\
\text { hour. July-September will see the } \\
\text { greatest escalation in heavy rain, } \\
\text { followed by October-December. } \\
\text { The decrease in summer volume } \\
\text { (July) at } 7 \% \text { is significant when } \\
\text { combined with } 2-3^{\circ} \text { C. Rise in } \\
\text { ground temperatures. }\end{array}$ & $\begin{array}{l}\text { Concrete canopies at Knowth and } \\
\text { Newgrange partially shelter the } \\
\text { kerbstones from horizontal rain. } \\
\text { Although volume remains constant } \\
\text { the shift towards short periods of } \\
\text { intense rainfall will alter wetting } \\
\text { and drying cycles considerably. } \\
\text { Concerns expressed for K1, } \\
\text { the exposed entrance stone at } \\
\text { Newgrange. }\end{array}$ \\
\hline
\end{tabular}

\section{Sensitivity}

Following consultation with stakeholders, impacts were numerically ranked according to the number of respondents concerned with each one. Based on these results, and other primary and secondary research, a number of issues in respect to the sensitivity of heritage values were noted. These 'key sensitivities' were then described and illustrated as a precursor to evaluating vulnerability. When describing the sensitivity of a site there may be a degree of overlap, e.g. between assemblages and systems. In the detailed evaluation, general sensitivities described under cultural landscape criteria can be refined in relation to specific elements, i.e. structures and buried deposits (Table 6). 
TABLE 6

SAMPLE OF CASE STUDY EVALUATION OF SENSITIVITY; E.G. EROSION AT BRÚ NA BÓINNE

\begin{tabular}{|c|c|c|}
\hline Impact & Mechanism & Comment \\
\hline \multicolumn{3}{|l|}{ Cultural Landscape } \\
\hline $\begin{array}{l}\text { Erosion - of earthen monuments, } \\
\text { river bank, and farmland possible } \\
\text { with increased episodes of severe } \\
\text { weather. Alterations to river bank } \\
\text { will impact on otter and kingfisher } \\
\text { (AL, pers. comm.). }\end{array}$ & $\begin{array}{l}\text { Heavy rain can lead to gullying } \\
\text { and erosion where vegetation has } \\
\text { been removed, or has died back } \\
\text { following drought. Intensification of } \\
\text { agriculture with bigger fields may } \\
\text { increase sensitivity to erosion. }\end{array}$ & $\begin{array}{l}\text { Geologically area has stable } \\
\text { glacial till = low risk of landslide. } \\
\text { Human activity (land use, } \\
\text { development) could make it } \\
\text { vulnerable to erosion (Mn, pers. } \\
\text { comm.). }\end{array}$ \\
\hline \multicolumn{3}{|l|}{ Buried Deposits } \\
\hline $\begin{array}{l}\text { Erosion and Exposure - erosion } \\
\text { of sites may result in partial } \\
\text { exposure e.g. gullying of earthen } \\
\text { mounds; or it may result in } \\
\text { complete loss. In some cases it } \\
\text { may reveal a previously unknown } \\
\text { feature. }\end{array}$ & $\begin{array}{l}\text { Heavy rain and increased river } \\
\text { flow - erosion of soil especially } \\
\text { where vegetation has been } \\
\text { removed, or has died back } \\
\text { following drought. Only when you } \\
\text { strip the vegetative cover lincl. } \\
\text { grassl that glacial till becomes } \\
\text { unstable (Mn, pers. comm.). }\end{array}$ & $\begin{array}{l}\text { Every field in the WHS has } \\
\text { archaeological potential, with } \\
\text { concentrations in some areas } \\
\text { such as around Newgrange (Cg, } \\
\text { pers. comm., Br, pers. comm.). } \\
\text { Careful management of land use } \\
\text { is the best way to stop erosion } \\
\text { (By, pers. comm.). }\end{array}$ \\
\hline \multicolumn{3}{|l|}{ Structures and Features } \\
\hline $\begin{array}{l}\text { Erosion - in respect of earthen } \\
\text { monuments and structures } \\
\text { possible with increased episodes } \\
\text { of severe weather. }\end{array}$ & $\begin{array}{l}\text { Heavy rain and increased river } \\
\text { flow (see flooding) - erosion of } \\
\text { soil especially where vegetation } \\
\text { has been removed, or has died } \\
\text { back following drought. }\end{array}$ & $\begin{array}{l}\text { Animal activity may contribute, } \\
\text { e.g. livestock trampling and } \\
\text { breaking grass cover. }\end{array}$ \\
\hline
\end{tabular}

\section{Adaptive capacity}

The United Nations Development Programme names four strategic areas (see below) where adaptive capacity should be analysed (GEF Global Support Programme, 2005). For the case studies these were subdivided further to characterize potential resilience.

I. Policies and Programmes (e.g. management structures, visitor management, legislative protections)

2. Information and Knowledge (e.g. climate change, human resources, population)

3. Implementation (e.g. conservation and maintenance)

4. Monitoring/Feedback

It is also important to consider capacity at the different scales at which it can be affected, e.g. local and individual as well as national and institutional. For example, when the Office of Public Works (OPW) are on Skellig Michael carrying out conservation works and managing visitors, adaptive capacity is high. During the winter the site is unmanned, however, and access can be very difficult, thus management capacity during this period is very low.

\section{Step 3: Identify likely hazards for each value under future climate using the matrix of impacts}

The production of a vulnerability hypothesis (who is vulnerable to what?) must be based on knowledge of the heritage values and of the likely impacts of climate change. The potential hazards for each heritage value under the projected future climate are initially identified while assessing sensitivity and exposure. In this step 
all the available evidence is combined in order to 'imagine' possible future impacts under projected conditions. Although the impacts matrix provides a useful reference for developing the vulnerability hypothesis, it should not be viewed as a definitive list of all potential impacts e.g. indirect impacts are not included (Daly, 2orra). In addition, individualized parameters such as topography, aspect, and material properties should be accounted for separately by the user. The uncertainty of the climate change model projections means that any hypothesis formulated on the basis of these future scenarios will need to be kept under constant review. Finally, the assessor has also to bear in mind that the stakeholders may be considering the issue of climate change impacts for the first time. Interpretation of stakeholder responses is the responsibility of the expert assessor and original contributions should be combined with collected data in a measured way.

\section{Step 4: Develop indicators for the elements of vulnerability}

The selection and application of indicators is a complex topic (Daly, 20I4; 20IIb). In general, indicators should be place based and relate to (at least) one of the key elements of vulnerability of heritage values to climate change impacts, i.e. exposure, sensitivity, or adaptive capacity. ${ }^{2}$ Quantifiable indicators for measuring vulnerability to climate change have been outlined in other disciplines and it may be possible to adapt some of these ideas to cultural heritage (Moss, et al., 200I; Sweeney, et al., 2002; Forbes \& Liverman, I996). Assessors should attempt to find the most useful indicators for the impacts with which they are concerned, and this can be challenging. Some examples of indicators proposed for ongoing evaluation at Skellig Michael are outlined in Table 7 by way of example.

\section{Step 5: Assess vulnerability by entering values for exposure, sensitivity, and adaptive capacity into the Causal Model}

A Causal Model developed by the author on the cause to consequence orientation (Table 8) is proposed for this step (Daly, 2008). In the model, sensitivity (S) and exposure (E) to hazard are positive values and adaptive capacity (AC) is negative. The 'measure of vulnerability' (MV) is then calculated; a positive value indicating vulnerability and a negative one resilience. The scale is a basic $\mathrm{I}-3$ range, where $\mathrm{I}$ is low.

In order to run the model, values for sensitivity, exposure, and adaptive capacity must be ascertained by interrogating the primary and secondary data. For example, gaps in the data for the case studies, due to a lack of site-based monitoring, were addressed by utilizing stakeholder information. The model therefore relies on the person entering the data having a high level of knowledge, gathered in steps $\mathrm{I}^{-4}$, in order to produce a credible set of values (Table 9). The application of indicators provides a quantifiable evidence base for the future review of this qualitative assessment.

\section{Step 6: Use stakeholder review to refine and communicate results}

Given the difficulties in obtaining quantifiable data appropriate to cultural heritage it was decided that 'Stakeholder Review' of the results would be used to provide validation. Appropriate feedback mechanisms need to be developed to suit the requirements of each group of stakeholders. At the case-study sites the stakeholders were sent hard copies of the final results and asked to complete a feedback form. Dialogue with 
TABLE 7

EXAMPLE OF PROPOSED INDICATORS OF VULNERABILITY FOR SKELLIG MICHAEL TO POTENTIAL CLIMATE CHANGE IMPACTS

\begin{tabular}{|c|c|c|c|}
\hline Impact & Indicator & Proxy for & Functional relationship \\
\hline Erosion of soil & $\%$ vegetation cover & Exposure to soil erosion & $\uparrow \%$ cover $=\downarrow$ exposure \\
\hline $\begin{array}{l}\text { Wave damage - salt } \\
\text { dosing and mechanical } \\
\text { action }\end{array}$ & $\begin{array}{l}\% \text { vegetation die back } \\
\text { on south east slope }\end{array}$ & $\begin{array}{l}\text { Exposure landscape to } \\
\text { increased frequency and } \\
\text { severity of storms/waves }\end{array}$ & $\downarrow \%$ cover $=\uparrow$ exposure \\
\hline Change in biodiversity & $\begin{array}{l}\text { Species survey (birds, } \\
\text { lichens) }\end{array}$ & $\begin{array}{l}\text { Sensitivity of natural } \\
\text { heritage to changing } \\
\text { climate }\end{array}$ & $\uparrow$ change $=\uparrow$ sensitivity \\
\hline $\begin{array}{l}\text { Changed microbiological } \\
\text { growth }\end{array}$ & $\begin{array}{l}\text { Lichen survey } \\
\text { Stone cube indicator tool }\end{array}$ & $\begin{array}{l}\text { Sensitivity of } \\
\text { microbiological organisms } \\
\text { to changes in climate }\end{array}$ & $\uparrow$ change $=\uparrow$ sensitivity \\
\hline $\begin{array}{l}\text { Structural damage by } \\
\text { wind - stone throw }\end{array}$ & $\begin{array}{l}\text { Number of stones } \\
\text { dislodged outside of } \\
\text { visitor areas/season }\end{array}$ & $\begin{array}{l}\text { Sensitivity of structures } \\
\text { to damage by wind }\end{array}$ & $\uparrow$ volume $=\uparrow$ sensitivity \\
\hline $\begin{array}{l}\text { Surface weathering by } \\
\text { wind and rain }\end{array}$ & Stone cube indicator tool & $\begin{array}{l}\text { Exposure of monuments } \\
\text { to surface erosion }\end{array}$ & $\begin{array}{l}\uparrow \text { measured loss }=\uparrow \\
\text { exposure }\end{array}$ \\
\hline $\begin{array}{l}\text { Disruption of access to } \\
\text { island }\end{array}$ & Number of boat landings & $\begin{array}{l}\text { Adaptive capacity } \\
\text { re. conservation and } \\
\text { maintenance regime }\end{array}$ & $\begin{array}{l}\downarrow \text { landings }=\downarrow \text { adaptive } \\
\text { capacity }\end{array}$ \\
\hline Increased visitor pressure & $\begin{array}{l}\text { Length of season } \\
\text { Number of boat landings }\end{array}$ & $\begin{array}{l}\text { Exposure to mechanical } \\
\text { damage }\end{array}$ & $\begin{array}{l}\text { Longer season }=\uparrow \\
\text { exposure }\end{array}$ \\
\hline All & $\begin{array}{l}\text { Human and civic } \\
\text { resources = No change } \\
\text { in professional staffing } \\
\text { levels }\end{array}$ & $\begin{array}{l}\text { Adaptive capacity } \\
\text { (management) }\end{array}$ & $\begin{array}{l}\text { Stagnant recruitment }=\downarrow \\
\text { adaptive capacity }\end{array}$ \\
\hline
\end{tabular}

TABLE 8

CAUSAL MODEL FOR SITE SPECIFIC EVALUATIONS OF VULNERABILITY TO CLIMATE CHANGE IMPACTS

\begin{tabular}{llllll}
\hline Matrix input & Indicators & Exposure (E) & Sensitivity (S) & $\begin{array}{l}\text { Adaptive } \\
\text { Capacity (AC) }\end{array}$ & $\begin{array}{l}\text { Measure of } \\
\text { Vulnerability (MV) }\end{array}$ \\
\hline Impact of concern & $\begin{array}{l}\text { Ind. } E . \\
\text { Ind. } S .\end{array}$ & 1 to 3 & 1 to 3 & 1 to 3 & $M=(E+S)-A C$ \\
& & & & & \\
& Ind. A.C. & & & & \\
\hline
\end{tabular}

TABLE 9

EXAMPLE OF CALCULATION OF MV - EROSION OF BURIED DEPOSITS, SKELLIG MICHAEL

\begin{tabular}{llllllll}
\hline $\begin{array}{l}\text { Climatic } \\
\text { parameter }\end{array}$ & $\begin{array}{l}\text { Sector or W. } \\
\text { H. value }\end{array}$ & Impact & Indicator & Sensitivity & Exposure & $\begin{array}{l}\text { Adaptive } \\
\text { Capacity }\end{array}$ & $\begin{array}{l}\text { Measure of } \\
\text { Vuln. }\end{array}$ \\
\hline Rainfall & $\begin{array}{l}\text { Buried } \\
\text { deposits }\end{array}$ & $\begin{array}{l}\text { Erosion \& } \\
\text { exposure }\end{array}$ & $\begin{array}{l}\% \\
\text { vegetation } \\
\text { cover }\end{array}$ & $\begin{array}{l}1 \text { - Low } \\
\text { (deposits } \\
\text { only in } \\
\text { monastery) }\end{array}$ & $\begin{array}{l}1-\text { Low } \\
\text { (sheltered } \\
\text { position) }\end{array}$ & $\begin{array}{l}\text { Medium } \\
\text { (rescue } \\
\text { excavation } \\
\text { possible) }\end{array}$ & \\
\hline
\end{tabular}


stakeholders throughout the assessment process is essential to ensure a final product that is both credible and relevant. Communication of the final results should be through presentations, publications, summary reports, and direct feedback to the contributing stakeholders. To establish an easily understandable and comparable ranking of vulnerabilities, a summary table of vulnerabilities (Figure 2) using the ICOMOS standard colour coding for expressing 'significance of change' was adopted for the case studies (e.g. Table Io) (ICOMOS, 20Iо).
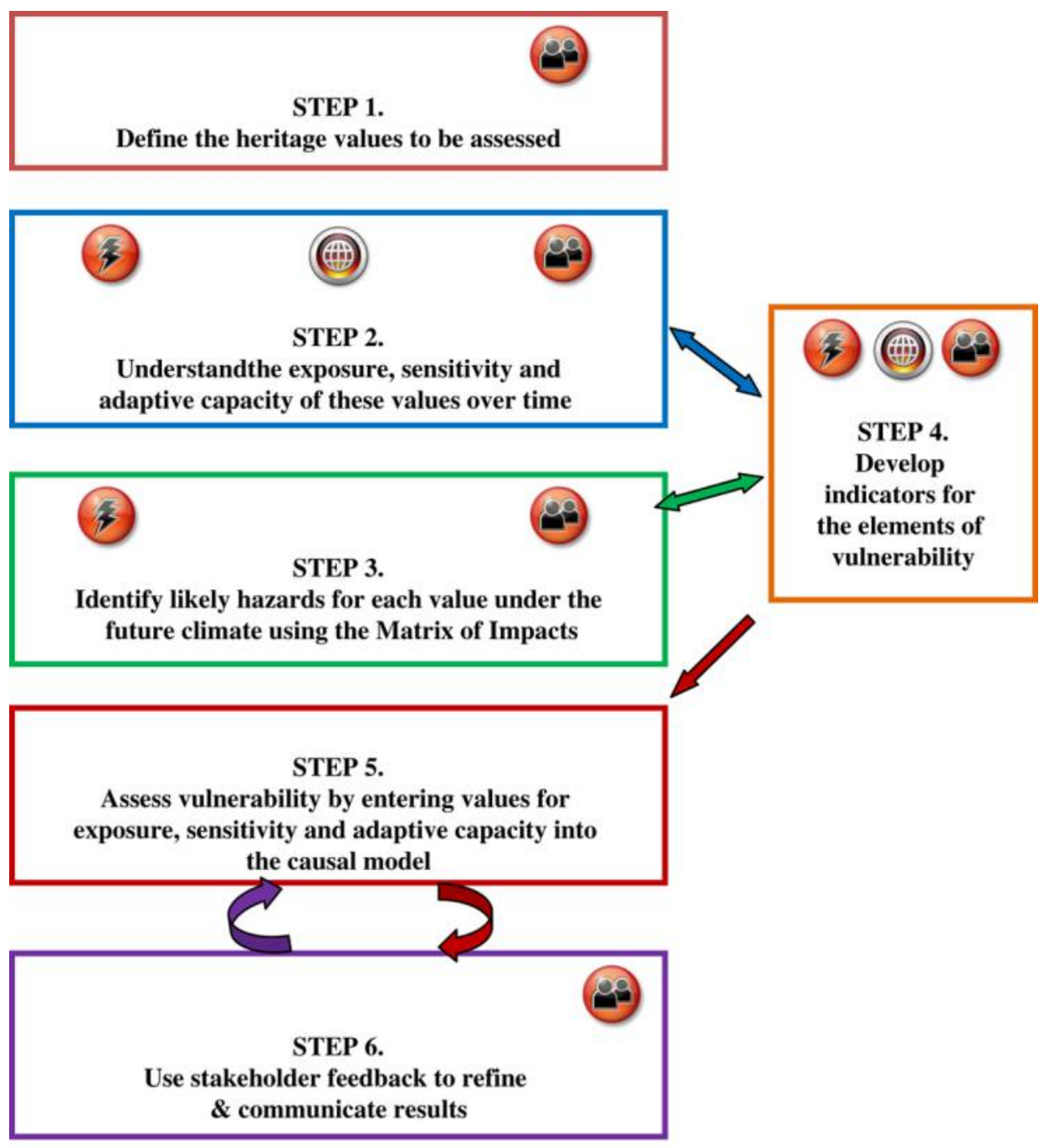

$=$ Consultation with stakeholders/experts

$=$ Climate change projections

$=$ Non-climatic factors

FIGURE 2 Six-step vulnerability framework for Cultural Heritage. 
TABLE 10

EXAMPLE OF SUMMARY FOR DECISION MAKERS OF PREDICTED CLIMATE CHANGE VULNERABILITIES RESULTS OF SKELLIG MICHAEL ASSESSMENT

\begin{tabular}{|c|c|c|c|}
\hline & Buried Deposits & Structures and features & Cultural Landscape \\
\hline \multirow{4}{*}{$\begin{array}{l}\text { Impacts for which Vulnerability is } \\
\text { High (priority } 1 \text { ) }\end{array}$} & \multirow{9}{*}{ Subsoil instability } & Pressure collapse & Soil Erosion \\
\hline & & Erosion of foundations & Loss of vegetation \\
\hline & & $\begin{array}{l}\text { Structural damage by } \\
\text { wind }\end{array}$ & $\begin{array}{l}\text { Change (loss/gain) of } \\
\text { species }\end{array}$ \\
\hline & & Access & Rock fall \\
\hline $\begin{array}{l}\text { Impacts for which Vulnerability is } \\
\text { Medium (priority 2) }\end{array}$ & & $\begin{array}{l}\text { Changed microbial } \\
\text { growth }\end{array}$ & Landslip \\
\hline \multirow{4}{*}{$\begin{array}{l}\text { Impacts for which Vulnerability } \\
\text { is Low }\end{array}$} & & Mechanical abrasion & Wave damage \\
\hline & & Infrastructural changes ${ }^{1}$ & Damage by water run-off \\
\hline & & Salt crystallization & \\
\hline & & $\begin{array}{l}\text { Thermoclastic } \\
\text { weathering }\end{array}$ & \\
\hline
\end{tabular}

Added following stakeholder review.

2 Although overall this is low, the west face of the south peak is extremely vulnerable to this form of weathering (Rourke, pers. comm.)

\section{Value and rankings}

The aim of an initial vulnerability assessment is to be as comprehensive as possible so that an understanding of the system-wide 'structure of vulnerability' can be gained (Adger, et al., 2004). Subsequent assessments can be designed to focus on specific values or impacts highlighted by the general analysis. The measure of vulnerability (MV) does not include a weighting for the relative value of a heritage asset or the degree to which that value will be diminished by any projected physical losses. Thus the final result requires interpretation before it is used to set priorities for adaptation or monitoring. ICOMOS recommends that the weight given to heritage values should be proportionate to the significance of the place and the impact of the change upon it (ICOMOS, 20I0: 2-I-5). Thus in the case of World Heritage properties most weight should be given to impacts on heritage values that contribute to the Outstanding Universal Value (OUV) defined for UNESCO.

Frequency of stakeholder responses was used to rank impacts for the case-study assessments, but this is not an accurate determination of relative significance. Some stakeholders will be more knowledgeable than others about specific topics, while some may be answering outside of their comfort zone. To allow for this, Woodside assigned a weighting to the stakeholders themselves and used that as a multiplier to create a ranking of impacts (2006). The weighting of stakeholder input relies on a judgement on the value of one person's views over another, however. It is unlikely to be a palatable task for site managers when processing contributions by their colleagues and peers, and therefore it is not suggested as part of the methodology. It is important, nonetheless, to be aware of the issue of competency when drawing conclusions from the views of stakeholders. 


\section{Conclusions}

Vulnerability assessment takes a system-wide approach, considering stakeholder input, socio-economic and institutional factors, as well as the physical hazards of climate change. This flexible multi-disciplinary analysis is well suited to cultural heritage management. The emphasis on case-study assessment, the holistic methodology, and the highlighting of capacity for adaptation to change, all contribute to this suitability. By assessing the coupled human-environment vulnerability assessments can accommodate the lack of accuracy inherent in future climate projections better than the statistical approach of risk analysis.

There are a wide variety of applications and methodologies in the literature, some are more akin to risk assessment but utilize the terminology of vulnerability. The conceptual six-step framework and key terms defined here provide a values-based methodology that is specific to cultural heritage. The procedure for applying the method is outlined and illustrated with case-study examples in order to aid those interested in conducting a vulnerability assessment. Assessment will be difficult, given the many uncertainties involved, and the framework provides a roadmap to get the process underway. It can be seen as the first step in a long journey of evidence gathering and review.

\section{Acknowledgements}

To all the stakeholders for Brú na Bóinne and Skellig Michael without whom the case study assessments would not have been possible; thanks to Grellan Rourke, Ana Dolan, and Clare Tuffy of the OPW; to the Climate for Culture project and Lola Kotova of Max Plank Institute for the REMO model case-study data; to DIT for the ABBEST scholarship which made this research possible, and to my supervisors Dr Tracy Pickerill and Prof. Peter Brimblecombe.

\section{Notes}

I Risk assessments deal with the combination of the probability of a consequence and its magnitude (Willows \& Connell, 2003: 43).

\section{Bibliography}

Adger, N.W. 2006. Vulnerability. Global Environmental Change, I6: 268-8I.

Adger, W.N., Brooks, N., Bentham, G., Agnew, M., \& Eriksen, S. 2004. New Indicators of Vulnerability and Adaptive Capacity. Technical Report. Tyndall Centre for Climate Change Research.

Colette, A. ed. 2007. Climate Change and World Heritage: Report on Predicting and Managing the Impacts of Climate Change on World Heritage and Strategy to Assist States Parties to Implement Appropriate Management Responses. Paris: UNESCO World Heritage Centre.

Daly, C. 2008. Climate Change and World Heritage: A Vulnerability Assessment of Brú Na Bóinne, Ireland. Unpublished thesis submitted for a Masters of Arts in World Heritage Studies. Cottbus: Brandenburg Technical University.

Daly, C. 20Ira. Climate Change and the Conservation of Archaeological Sites: A Review of Impacts Theory. Conservation and Management of Archaeological Sites, I3 (4): 293-310. 
Daly, C. 20Irb. The Potential for Indicators in the Management of Climate Change Impacts on Cultural Heritage. In: Cultural Heritage Preservation. Proceedings of the European Workshop on Cultural Heritage Preservation. Ewchp 20II, September 20II, Berlin, Germany, pp. 2-28.

Daly, C. 20r4. A Cultural Heritage Management Methodology for Assessing the Vulnerabilities of Archaeological Sites to Predicted Climate Change Focussing on Ireland's Two World Heritage Sites. Unpublished Doctoral thesis, Dublin Institute of Technology [accessed December 20I4]. Available at: <Http://Arrow.Dit.Ie/Builtdoc/I $3 />$.

Daly, C., Cox, P., Cuffe-Fitzgerald, A., Dubs, B., \& Pickerill, T. 20Iо. Monitoring Impacts of Climate Change on Built Heritage. Report for the Department of Environment Heritage and Local Government by ICOMOS Ireland [accessed October 20I4]. Available at: <www.Icomosireland.Ie.>

Douglas, M. \& Wildavsky, A.B. 1982. Risk and Culture: An Essay on the Selection of Technical and Environmental Dangers. Berkeley: University of California Press.

Forbes, D.L. \& Liverman, D.G.E. 1996. Geological Indicators in the Coastal Zone. In: A.R. Berger \& W.J. Iams, eds. Geoindicators. Assessing Rapid Environmental Changes in Earth Systems. Rotterdam.

Ford, J.D. \& Smit, B. 2004. A Framework for Assessing the Vulnerability of Communities in the Canadian Arctic to Risks Associated with Climate Change. Arctic, 57: 389-400.

Gef Global Support Programme 2005. Resource Kit for National Capacity Self-Assessment. United Nations Development Programme.

Hinkel, J. 20II. 'Indicators of vulnerability and adaptive capacity': Towards a Clarification of the Science-Policy Interface. Global Environmental Change, 21: 198-208.

Hinkel, J. \& Klein, J.T. 2006. Integrating Knowledge for Assessing Coastal Vulnerability to Climate Change. In: L. Mcfadden, R.J. Nicholls, \& E.C. Penning-Rowsell, eds. Managing Coastal Vulnerability: An Integrated Approach. Netherlands: Elsevier Science.

Holden, J., West, L.J., Howard, A.J., Maxfield, E., Panter, I., \& Oxley, J. 2006. Hydrological Controls of In Situ Preservation of Waterlogged Archaeological Deposits. Earth Science Reviews, 78: 59-83.

ICOMOS 20I0. Guidance on Heritage Impact Assessments for Cultural World Heritage Properties. Paris: ICOMOS.

Jacob, D., Elizalde, A., Haensler, A., Hagemann, S., Kumar, P., Pdzun, R., Rechid, D., Remedio, R. A., Saeed, F., Sieck, K., Teichmann, C., \& Wilhelm, C. 20I2. Assessing the Transferability of the Regional Climate Model Remo to Different Coordinated Regional Climate Downscaling Experiment (Cordex) Regions. Atmosphere, 3: I8I-99.

Luers, A.L., Lobell, D.B., Sklar, L.S., Addams, C.L., \& Matson, P.A. 2003. A Method for Quantifying Vulnerability, Applied to the Agricultural System of the Yaqui Valley, Mexico. Global Environmental Change, I3: $255-67$.

Marshall, P.A. \& Johnson, J.E. 2007. Chapter 24. The Great Barrier Reef and Climate Change: Vulnerability and Management Implications. In: J.E. Johnson \& P. Marshall, eds. Climate Change and the Great Barrier Reef: A Vulnerability Assessment. Australia: Great Barrier Reef Marine Park Authority and Australian Greenhouse Office.

McCarthy, J., Canziani, O.F., Leary, N.A., Dokken, D.J., \& White, K.S. eds. 200I. Climate Change 200I: Impacts, Adaptation, and Vulnerability. Contribution of Working Group II to the Third Assessment Report of the Intergovernmental Panel on Climate Change. Cambridge: Cambridge University Press.

Moss, R.H., Brenkert, A.L., \& Malone, E.L. 200I. Vulnerability to Climate Change: A Quantitative Approach. Report prepared for the United States Department of Energy. Pacific Northwest National Laboratory.

Schröter, D., Polsky, C., \& Patt, A.G. 2005. Assessing Vulnerabilities to the Effects of Global Change: An Eight Step Approach. Mitigation and Adaptation Strategies for Global Change, 10: 573-96.

Sweeney, J., Donnelly, A., Mcelwain, L., \& Jones, M. 2002. Climate Change Indicators for Ireland. Environmental Rtdi Programme 2000-06 Final Report. Environmental Protection Agency.

The Allen Consulting Group 2005. Climate Change Risk and Vulnerability — Final Report. Canberra: Australian Greenhouse Office [accessed October 20I4]. Available at: <www.Greenhouse.Gov.Au>.

Toscano, M.A. 2004. Assessment of Vulnerability of Coastal Cultural and Archaeological Resources to Sea-Level Rise and Coastal Processes, Gulf Islands National Seashore, Florida and Mississippi: Recommendations for Protection and Preservation. Geoscientists-In-The-Parks Document, 2003-Guis. Denver, Colorado: US National Parks and Wildlife Service. 
Turner, B.L., Kasperson, R.E., Matson, P.A., Mccarthy, J.J., Corell, R.W., Christensen, L., Eckley, N., Kasperson, J.X., Luers, A., Martello, M.L., Polsky, C., Pulsipher, A., \& Schiller, A. 2003a. A Framework for Vulnerability Analysis in Sustainability Science. Proceedings of the National Academy of Sciences of the United States of America, I00: 8074-79.

Turner, B.L., Matson, P.A., Mccarthy, J.J., Corell, R.W., Christensen, L., Eckley, N., Hovelsrud-Broda, G.K., Kasperson, J.X., Kasperson, R.E., Luers, A., Martello, M.L., Mathiesen, S., Naylord, R., Polsky, C., Pulsipher, A., Schiller, A., Selin, H., \& Tyler, N. 2003 b. Illustrating the Coupled Human-Environment System for Vulnerability Analysis: Three Case Studies. Proceedings of the National Academy of Sciences of the United States of America, IO०: $8080-85$.

Viles, H.A. 2002. Implications of Future Climate Change for Stone Deterioration. In: S. Siegesmund, T. Weiss, \& A. Vollbrecht, eds. Natural Stone Weathering Phenomena, Conservation Strategies and Case Studies. London: Geological Society.

Willows, R.I. \& Connell, R.K. eds. 2003. Climate Adaptation: Risk, Uncertainty and Decision-Making. Oxford: UKCIP.

Woodside, R. 2006. World Heritage and Climate Change: Developing a Framework for Assessing Vulnerability. Unpublished Msc Built Environment: Sustainable Heritage, University College London.

\section{Notes on contributor}

Cathy Daly is an archaeological and museums conservator with a research interest in conservation management. She holds primary degrees in'Ancient History and Archaeology and in the Conservation of Archaeological Artefacts, and a Masters degree in World Heritage Studies. In 20I0 Cathy was lead author on Monitoring Impacts of Climate Change on Built Heritage, a report commissioned from ICOMOS Ireland by the Department of Environment Heritage and Local Government. In 20I4 she was awarded a $\mathrm{PhD}$ by the Dublin Institute of Technology. In her doctoral research transferable methodologies for the site level assessment and measurement of climate change vulnerabilities were developed and applied in practice at Ireland's two World Heritage sites. Cathy is a founding and current member of the Irish National Committee of the Blue Shield.

Correspondence to: Cathy Daly. Email: cathydaly73@gmail.com 